\title{
Efek Sinergis Kombinasi Ekstrak Etanolik Kayu Secang dan Rimpang Lempuyang pada Sel Kanker Payudara MCF-7
}

\section{The Synergistic Effect of Sappan Wood and Bitter Ginger Rhizome Ethanolic Extract in MCF-7 Human Breast Cancer Cell Lines}

\author{
Sari Haryanti", Ika Yanti M. Sholikhah, Yuli Widiyastuti \\ Balai Besar Penelitian dan Pengembangan Tanaman Obat dan Obat Tradisional, Tawangmangu, Indonesia \\ *E-mail: sari.haryanti@gmail.com
}

Diterima: 23 Agustus 2018

Direvisi: 24 Januari 2019

Disetujui: 7 Februari 2019

\begin{abstract}
Abstrak
Kanker merupakan salah satu penyakit kritis, kronis, kompleks, dan menjadi penyebab kematian yang cukup tinggi di dunia. Kayu secang (Caesalpinia sappan L.) mengandung senyawa brazilin dan brazilein, sedangkan rimpang lempuyang (Zingiber zerumbet L.) mengandung zerumbon. Senyawa tersebut menunjukkan aktivitas sitotoksik dengan mekanisme yang berbeda. Penelitian ini bertujuan untuk mengkaji efek kombinasi kayu secang dan rimpang lempuyang. Kayu secang dan rimpang lempuyang dimaserasi dengan etanol 96\% 3x24 jam, disaring, dan diuapkan hingga diperoleh ekstrak kering. Uji sitotoksik pada sel MCF-7 dilakukan dengan MTT assay. Nilai index kombinasi (CI) dianalisis dengan CompuSyn berdasarkan hasil sitotoksik kombinasi. Profil siklus sel dan induksi apoptosis dikaji dengan flow cytometry. Ekstrak secang dan rimpang lempuyang menunjukkan efek sitotoksik pada sel MCF-7 dengan nilai IC $_{50}$ berturut-turut 30 dan $155 \mu \mathrm{g} / \mathrm{mL}$. Kombinasi ekstrak secang $15 \mu \mathrm{g} / \mathrm{mL}$ dan lempuyang $8,12,24$, dan $60 \mu \mathrm{g} / \mathrm{mL}$ menghasilkan efek sinergis dengan nilai CI 0,57-0,85. Kombinasi secang $15 \mu \mathrm{g} / \mathrm{mL}$ dengan lempuyang 8 dan $24 \mu \mathrm{g} / \mathrm{mL}$ menunjukkan penghambatan siklus sel di fase G2/M. Kombinasi keduanya juga meningkatkan terjadinya induksi apoptosis dibandingkan kontrol dan perlakuan tunggalnya. Kombinasi ekstrak etanolik kayu secang dan rimpang lempuyang menghasilkan efek sitotoksik yang sinergis. Sinergisme kombinasi terjadi melalui penghambatan siklus sel di fase G2/M dan induksi apoptosis.
\end{abstract}

Kata kunci: Caesalpinia sappan L; Zingiber zerumbet L; Indeks kombinasi

\begin{abstract}
Cancer is one of critical, chronic, and complex disease, also becoming the high cause of death in the world. Brazilin and brazilein in sappan wood (Caesalpinia sappan L.) and zerumbone in bitter ginger rhizome (Zingiber zerumbet L.) are known having cytotoxic activity with different mechanisms. This study aimed to examine combination effect of sappan wood and bitter ginger rhizome. Sappan wood and bitter ginger rhizomes macerated with ethanol $96 \%$ for $3 \times 24$ hours, filtered, and evaporated to obtain dried extract.Cytotoxic effect on MCF-7 cells was done using MTT assay. Combination Index (CI) was determined by CompuSyn based on the result of cytotoxic combination. Cell cycle profile and apoptosis induction was analyzed by flow cytometry. Sappan wood extracts and bitter ginger rhizome exhibited cytotoxic effects on MCF-7 cells with the IC50 values of 30 and $155 \mu \mathrm{g} / \mathrm{mL}$ respectively. The combination of sappan wood $15 \mu \mathrm{g} / \mathrm{mL}$ and bitter ginger 8, 12, 24, and $60 \mu \mathrm{g} / \mathrm{mL}$ produced synergistic effect with the CI value of 0.57-0.85. Sappan wood $15 \mu \mathrm{g} / \mathrm{mL}$ combined with bitter ginger 8 and $24 \mu \mathrm{g} / \mathrm{mL}$ showed cell cycle inhibition at G2/M phase. The combination also increased apoptosis induction compared to untreated cells and its single treatment.The combination of sappan wood ethanolic extracts and bitter ginger rhizome showed synergistic cytotoxic effect. Its synergism effect revealed through cell cycle arrested at G2/M phase and acceleration of apoptotic induction.
\end{abstract}

Keywords: Caesalpinia sappan L; Zingiber zerumbet L; Combination index 


\section{PENDAHULUAN}

Sekitar $70 \%$ populasi penduduk di berbagai wilayah dunia telah memanfaatkan produk berbasis tumbuhan (herbal) sebagai upaya pemeliharaan kesehatan primer. Produk herbal digunakan sebagai ramuan tunggal, kombinasi ramuan, atau kombinasi ramuan dan obat konvensional. Ketika ramuan digunakan dalam kombinasi, efek yang dihasilkan bisa menjadi lebih kompleks karena berbagai kemungkinan interaksi dapat terjadi. Interaksi kombinasi yang diharapkan adalah manfaat terapeutik tambahan atau sinergis. Terapi kombinasi diperlukan untuk pengobatan penyakit kritis, kronis dan kompleks, seperti kanker, AIDS, dan tuberkulosis paru. ${ }^{1}$

Kanker masih menjadi salah satu penyebab kematian tertinggi di dunia. Kanker payudara merupakan jenis kanker yang paling banyak diderita wanita. Negara di Asia dengan jumlah kasus kanker payudara tertinggi pada tahun 2012 adalah Cina (187.213 kasus), selanjutnya India (144.937 kasus), Jepang (55.710 kasus), Indonesia (48.998), dan Pakistan (34.038 kasus). Berdasarkan data tersebut, estimasi prevalensi kanker payudara di Indonesia adalah 40,3 per 100.000 penduduk, dengan estimasi angka kematian sebesar 16,6 per $100.000 .^{2}$

Kanker merupakan penyakit dengan etiologi dan patofisiologi yang sangat kompleks. Sel kanker sangat mudah dan cepat menjalani adaptasi molekuler, sehingga spesifisitas dan efisensi terapi secara tunggal cukup sulit mencapai efek pengobatan optimal. Selain itu, agen kemoterapi konvensional saat ini seringkali meninggalkan masalah klinis berupa efek toksik pada organ lain serta berkembangnya peristiwa resistensi. Bahan alami, terutama tumbuhan, dapat saling dikombinasikan sehingga mencapai efek sinergis dengan meningkatkan sitotoksisitas pada sel kanker, serta meningkatkan sensitivitas respon imun untuk melawan kanker. ${ }^{3}$
Penemuan kombinasi tumbuhan yang menghasilkan interaksi sinergis merupakan strategi yang cukup potensial dalam pengembangan terapi kanker payudara. Beberapa tumbuhan diketahui memiliki mekanisme yang berbeda dalam menghasilkan efek sitotoksik. Kajian perbedaan mekanisme aksi dapat digunakan sebagai salah satu dasar dalam penentuan kombinasi tumbuhan. Sebagai contoh, secang (Caesalpinia sappan L.) merupakan tumbuhan dalam famili Leguminosae yang digunakan secara luas dalam pengobatan tradisional di Asia. $^{4}$ Ekstrak etanolik kayu secang memiliki efek sitotoksik kuat terhadap sel kanker payudara 4T1. Namun demikian, aktivitas antimetastasis secang tergolong lemah dibandingkan daun awar-awar (Ficus septica). ${ }^{5}$ Secang menghambat siklus sel fase $\mathrm{G} 2 / \mathrm{M}$ pada sel MCF-7 dan MCF7/HER2. ${ }^{6,7}$

Lempuyang atau Zingiber zerumbet L. Roscoe ex Sm. merupakan tumbuhan famili Zingiberaceae. Di Asia Tenggara, rimpang lempuyang digunakan dalam pengobatan tradisional untuk mengatasi radang, demam, sakit gigi, gangguan pencernaan, dan meredakan nyeri. ${ }^{8}$ Zerumbon adalah salah satu senyawa seskuiterpen utama yang berkontribusi dalam aktivitas farmakologi lempuyang. ${ }^{9}$ Zerumbon merupakan salah satu agen kemopreventif potensial untuk kanker kolon dan kulit. ${ }^{10,11}$ Zerumbon menurunkan ekspresi VEGF dan NF- $\mathrm{NB}$ sehingga menghambat angiogenesis pada sel kanker lambung. ${ }^{12}$

Perbedaan mekanisme secang dan lempuyang menarik untuk diteliti lebih lanjut. Kombinasi keduanya diharapkan dapat menghasilkan efek sinergis. Penelitian ini dilakukan untuk mengkaji aktivitas sitotoksik, profil siklus sel, dan induksi apoptosis ekstrak etanolik kayu secang dan rimpang lempuyang, baik tunggal maupun kombinasi. 


\section{METODE}

Penelitian dilakukan pada tahun 2017 di laboratorium Biologi Molekuler, Balai Besar Penelitian dan Pengembangan Tanaman Obat dan Obat Tradisional (B2P2TO2T), Tawangmangu.

\section{Alat dan bahan \\ Alat}

ELISA Reader Biorad dan flow cytometry BD Accuri C6.

\section{Bahan}

Simplisia kayu secang dan rimpang lempuyang diperoleh dari Laboratorium Pascapanen, B2P2TO2T. Kedua simplisia diserbuk menggunakan blender, kemudian dimaserasi dengan etanol $96 \%$ selama $3 \times 24$ jam secara terpisah. Maserat kemudian disaring, dan diuapkan pada oven suhu $40{ }^{\circ} \mathrm{C}$ hingga didapatkan ekstrak kering kayu secang dan rimpang lempuyang.

Sel kanker payudara MCF-7 merupakan koleksi Laboratorium Biologi Molekuler, B2P2TO2T, diperoleh dari American Type Culture Collection (ATCC). Sel dipelihara dalam media kultur Eagle's Minimum Essential Medium (EMEM, Sigma) yang ditambahkan Fetal Bovine Serum (FBS) 10\% (Gibco), dan penisilin-streptomisin 1\% (Gibco).

\section{Prosedur kerja}

Uji sitotoksik dilakukan dengan metode MTT assay pada sel MCF-7. Sel yang telah konfluen dalam cawan dipanen dengan tripsin EDTA 0,25\% (Sigma). Sel dihitung dengan hemositometer. Sejumlah $10^{3}$ sel/sumuran didistribusikan ke dalam 96well plate. Sel diinkubasi selama 48 jam di dalam inkubator $\mathrm{CO}_{2} 5 \%, 37{ }^{\circ} \mathrm{C}$. Ekstrak $10 \mathrm{mg}$ dalam $100 \mu \mathrm{L}$ DMSO, diencerkan dalam media kultur dengan konsentrasi lempuyang 20, 40, 80, 150, 200, 250 $\mu \mathrm{g} / \mathrm{mL}$; secang 10, 20, 30, 32, 35, 40 $\mu \mathrm{g} / \mathrm{mL}$. Ekstrak dimasukkan dalam sumuran, masing-masing perlakuan sebanyak 3 sumuran (triplo). Sel diinkubasi selama 24 jam di dalam inkubator $\mathrm{CO}_{2}$. Pada akhir inkubasi, media dibuang, sel dicuci dengan phospate buffer saline (PBS) $100 \mu \mathrm{L} /$ sumuran, ditambahkan MTT $100 \mu \mathrm{L} /$ sumuran, diinkubasi dalam inkubator $\mathrm{CO}_{2}$ selama 3 jam. Selanjutnya ditambahkan stopper sodium dodesil sulfat (SDS, Sigma) 10\% dalam $\mathrm{HCl} 0,01 \mathrm{~N}$. Plate dibiarkan semalam pada suhu kamar terlindung dari cahaya, dibaca dengan ELISA reader panjang gelombang $595 \mathrm{~nm}^{13}$ Uji sitotoksik kombinasi dilakukan dengan seri konsentrasi lempuyang $8,12,24,60$ $\mu \mathrm{g} / \mathrm{mL}$; secang $2,3,6,15 \mu \mathrm{g} / \mathrm{mL}$.

Profil siklus sel dianalisis dengan flow cytometry. Sel dipanen, dihitung menggunakan hemositometer, kemudian didistribusikan ke dalam 6-well plate, yang terdiri dari 6 well (sumuran). Masingmasing sumuran berisi sejumlah $1 \times 10^{7}$ sel dalam 1,5 mL media kultur, kemudian diinkubasi selama 2x24 jam. Selanjutnya, sel dalam sumuran diberikan 6 perlakuan yaitu ekstrak secang $15 \mu \mathrm{g} / \mathrm{mL}$, lempuyang 8 dan $24 \mu \mathrm{g} / \mathrm{mL}$, kombinasi secang $15 \mu \mathrm{g} / \mathrm{mL}$ dengan lempuyang $8 \mu \mathrm{g} / \mathrm{mL}$, kombinasi secang $15 \mu \mathrm{g} / \mathrm{mL}$ dengan lempuyang $24 \mu \mathrm{g} / \mathrm{mL}$, dan kontrol sel tanpa perlakuan, kemudian diinkubasi dalam inkubator $\mathrm{CO}_{2}$ selama 24 jam. Pada akhir perlakuan, media dalam setiap sumuran dimasukkan dalam conical yang berbeda. Tiap conical diberi tanda dan selanjutnya digunakan untuk perlakuan yang sama. Sel dicuci dengan $500 \mu \mathrm{L}$ PBS, kemudian PBS dimasukkan ke dalam conical. Sel ditambahkan $200 \mu \mathrm{L}$ tripsinEDTA $0,25 \%$, diinkubasi 3 menit, diberikan $500 \mu \mathrm{L}$ media dan diresuspensi. Suspensi sel dimasukkan dalam conical yang sama, dipusingkan $500 \mathrm{rpm}$ selama 5 menit. Endapan difiksasi dengan etanol $70 \%$ dingin, dibiarkan 1 jam dalam suhu ruang, dipusingkan $2000 \mathrm{rpm}$ selama 3 menit, dicuci dengan PBS, dipusingkan kembali, ditambahkan $400 \mu \mathrm{L}$ reagen PI (propidium iodide) $1 \mathrm{mg} / \mathrm{mL}$ (Sigma), 10 $\mathrm{mg} / \mathrm{mL}$ RNAse (Sigma) dan 0,1\% (v/v) Triton-X 100 (Sigma). Sel diresuspensikan dan diinkubasi 5 menit dalam ruang gelap, 
kemudian dibaca dengan flow cytometer.

Untuk pengamatan apoptosis, tahapan cara kerja hingga diperoleh endapan sel, sama dengan profil siklus sel. Endapan sel kemudian diresuspensi dengan $100 \mu \mathrm{L}$ binding buffer (BD), $2 \mu \mathrm{L}$ Anexin-V (BD) dan $2 \mu \mathrm{L}$ PI (BD), lalu diinkubasi dalam ruang gelap selama 10 menit. Suspensi sel dibaca dengan flow cytometer.

\section{Analisis Data}

Data MTT assay dianalisis dengan regresi linier Excel MS Office 2013, sehingga diperoleh nilai $\mathrm{IC}_{50}$. Analisis nilai $\mathrm{CI}$ (indeks kombinasi) menggunakan software CompuSyn. Interpretasi nilai CI terlihat pada Tabel 1. Data flow cytometer dianalisis menggunakan Accuri C6 software.

Tabel 1. Interpretasi nilai CI

\begin{aligned} & \hline \multicolumn{1}{c}{ CI } \multicolumn{1}{c}{ Interpretasi } \\ & \hline$<0.1$ Sinergis sangat kuat \\ & $0.10-0.30$ Sinergis kuat \\ & $0.30-0.70$ Sinergis \\ & $0.70-0.90$ Sinergis menengah \\ & $0.90-1.10$ Mendekati aditif \\ & $1.10-1.45$ Antagonis menengah \\ & $1.45-3.30$ Antagonis \\ &$>3.3$ Antagonis kuat \\ & \\ & \hline\end{aligned}

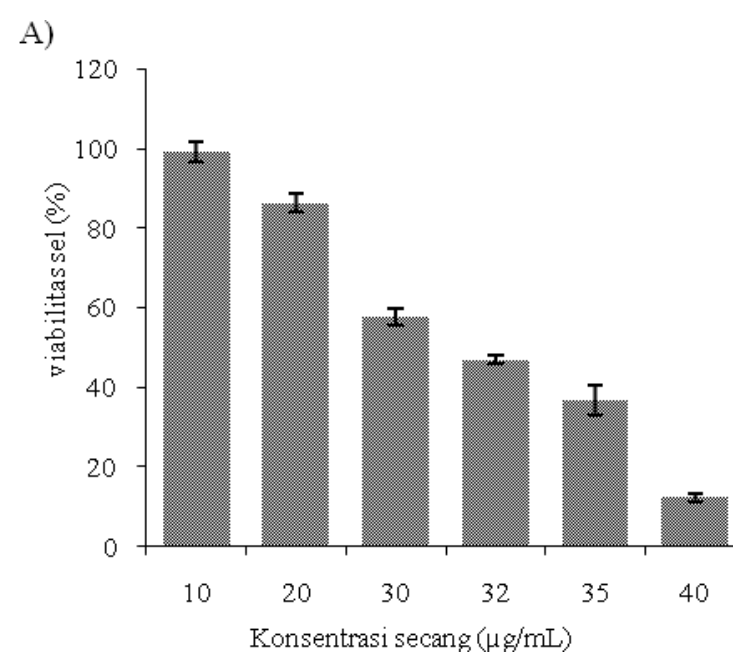

\section{HASIL DAN PEMBAHASAN}

Berdasarkan analisis hasil MTT assay, ekstrak etanolik kayu secang dan rimpang lempuyang mampu menurunkan viabilitas sel MCF-7. Hasil perhitungan persentase viabilitas dan hubungannya dengan konsentrasi ekstrak dapat dilihat pada grafik di Gambar 1. Secang memberikan efek yang lebih baik dengan nilai $\mathrm{IC}_{50} 30$ $\mu \mathrm{g} / \mathrm{mL}$, jauh lebih poten dibandingkan $\mathrm{IC}_{50}$ lempuyang sebesar $155 \mu \mathrm{g} / \mathrm{mL}$.

Penelitian lain melaporkan ekstrak metanol kayu secang menunjukkan efek sitotoksik pada sel kanker paru A-549 dengan nilai IC $_{50} 40 \mu \mathrm{g} / \mathrm{mL}^{14}$, sedangkan pada sel kanker serviks HeLa nilai IC $_{50} 26$ $\mu \mathrm{g} / \mathrm{mL} .{ }^{15}$ Hasil penelitian Nurzijah, dkk., 2012, ekstrak etanol kayu secang memiliki efek sitotoksik terhadap sel kanker payudara T47D dengan nilai $\mathrm{IC}_{50} 35$ $\mu \mathrm{g} / \mathrm{mL}{ }^{16}$ Penelitian lain menggunakan ekstrak heksan rimpang lempuyang pada sel Human Myeloid Leukemia HL60 memberikan nilai $\mathrm{IC}_{50} 63,7 \mu \mathrm{g} / \mathrm{mL} .^{17}$

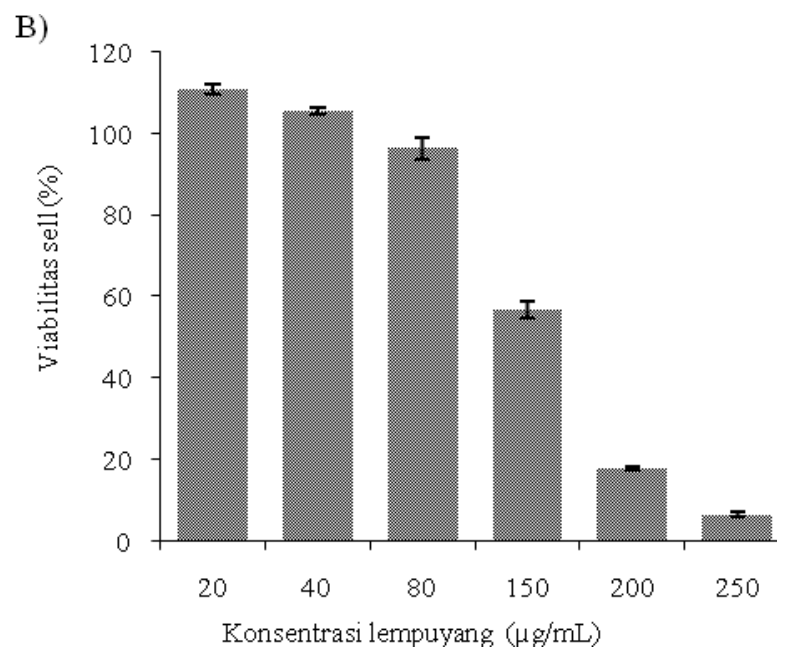

Gambar 1. Grafik konsentrasi ekstrak secang (A) dan lempuyang (B) tunggal vs viabilitas sel. Masing-masing perlakuan diulang tiga kali. Data persentase viabilitas sel merupakan representasi dari rerata \pm SD 
Tabel 2. Viabilitas sel MCF-7 setelah diberi perlakuan kombinasi ekstrak kayu secang dan rimpang lempuyang

\begin{tabular}{|c|c|c|c|c|c|c|}
\hline \multirow{7}{*}{ 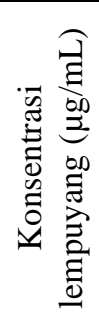 } & & \multicolumn{5}{|c|}{ Viabilitas kombinasi (\%) } \\
\hline & & 0 & 2 & 3 & 6 & 15 \\
\hline & 0 & - & $93,4 \pm 3,2$ & $93,3 \pm 1,9$ & $94,9 \pm 1,5$ & $95,1 \pm 2,4$ \\
\hline & 8 & $96,0 \pm 3,8$ & $96,9 \pm 0,3$ & $98,6 \pm 1,8$ & $98,0 \pm 1,3$ & $88,0 \pm 2,1$ \\
\hline & 12 & $94,9 \pm 3,2$ & $97,5 \pm 4,4$ & $95,1 \pm 2,0$ & $93,1 \pm 2,1$ & $76,8 \pm 1,1$ \\
\hline & 24 & $102,6 \pm 2,8$ & $100,1+1,3$ & $100,4 \pm 7,3$ & $100,4 \pm 2,2$ & $64,9 \pm 5,7$ \\
\hline & 60 & $110,0 \pm 3,8$ & $101,0 \pm 1,7$ & $100,2 \pm 2,1$ & $86,5 \pm 0,4$ & $9,8+3,1$ \\
\hline
\end{tabular}

Ket.: masing-masing perlakuan kombinasi diulang tiga kali. Data persentase viabilitas sel merupakan representasi dari rerata $\pm \mathrm{SD}$
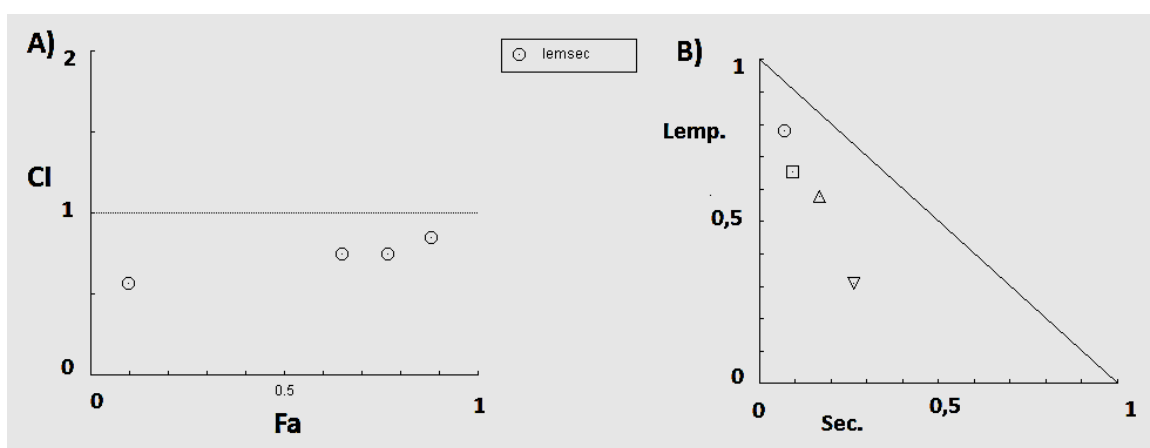

Gambar 2. Nilai CI (A) dan isobologram (B) kombinasi ekstrak kayu secang dan rimpang lempuyang dengan CompuSyn. Nilai $\mathrm{CI}<1$ dan point kombinasi di bawah garis miring isobologram menunjukkan efek sinergis. Fa merepresentasikan viabilitas sel, $\mathrm{Fa}=1$ artinya viabilitas sel $100 \%, \mathrm{Fa}<1$ viabilitas sel $0 \%$

Kombinasi secang dan lempuyang masing-masing menggunakan konsentrasi tidak lebih dari $1 / 2 \mathrm{IC}_{50}$. Hasil MTT assay menunjukkan kombinasi lempuyang dengan secang konsentrasi kurang dari 15 $\mu \mathrm{g} / \mathrm{mL}$ belum berpengaruh nyata terhadap penurunan viabilitas sel. Efek penurunan viabilitas terlihat pada kombinasi secang $15 \mu \mathrm{g} / \mathrm{mL}$ dengan lempuyang 8, 12, 24, dan $60 \mu \mathrm{g} / \mathrm{mL}$ (Tabel 2). Selanjutnya, empat seri kombinasi tersebut dianalisis menggunakan software CompuSyn. Kombinasi secang $15 \mu \mathrm{g} / \mathrm{mL}$ dan lempuyang $8,12,24$, dan $60 \mu \mathrm{g} / \mathrm{mL}$ menghasilkan efek sinergis dengan nilai combination index $(\mathrm{CI})<1$ berturut-turut $0,85,0,75,0,74$, dan 0,57 ; serta poin kombinasi berada di bawah garis aditif isobologram (Gambar 2). Analisis CompuSyn juga menunjukkan kombinasi kedua ekstrak memiliki nilai dose reduction index $(\mathrm{DRI})>1$ mengindikasikan efek saling memperkuat.
Selanjutnya, mekanisme sitotoksik dikaji melalui pengamatan siklus sel dan apoptosis pada dua kombinasi, yaitu secang $15 \mu \mathrm{g} / \mathrm{mL}$ dengan lempuyang 8 dan $24 \mu \mathrm{g} / \mathrm{mL}$ menggunakan flow cytometer. Pemilihan konsentrasi berdasarkan hasil viabilitas kombinasi seperti terlihat pada Tabel 2.

Kombinasi secang:lempuyang (15:8) dan $\quad(15: 24) \quad \mu \mathrm{g} / \mathrm{mL}$ berturut-turut menghasilkan viabilitas $88,0 \%$ dan $64,9 \%$. Besaran nilai viabilitas tersebut diharapkan dapat merepresentasikan jumlah sel hidup yang cukup untuk menggambarkan gambaran profil siklus sel maupun kematian sel.

Profil siklus sel perlakuan tunggal ekstrak kayu secang $15 \mu \mathrm{g} / \mathrm{mL}$ tunggal menunjukkan peningkatan populasi sel di fase $\mathrm{G} 2 / \mathrm{M}$ menjadi $42,3 \%$, sedangkan kontrol tanpa perlakuan 27,6\%. Ekstrak rimpang lempuyang 8 dan $24 \mu \mathrm{g} / \mathrm{mL}$ hanya sedikit meningkat, berturut-turut $32,3 \%$ 
dan 30,7\%. Profil siklus sel kombinasi menunjukkan dominasi efek secang sehingga menghambat siklus sel di fase G2/M berturut-turut $43,5 \%$ dan $41,5 \%$ (Gambar 3). Sejalan dengan hasil penelitian ini, Handayani dkk. 2017, melaporkan senyawa brazilin dan brazilein yang diisolasi dari kayu secang menghambat siklus sel di fase $\mathrm{S}$ dan $\mathrm{G} 2 / \mathrm{M}$ pada sel kanker kolon WiDr. ${ }^{18}$ Pada sel multiple myeloma U266, brazilin memperlihatkan hambatan pada fase G2/M. ${ }^{19}$

Peningkatan populasi di fase $\mathrm{G} 2 / \mathrm{M}$ menunjukkan terhentinya siklus sel di fase tersebut. Pembuatan protein dan organel sel serta persiapan menuju pembelahan sel (mitosis) merupakan peristiwa yang terjadi pada fase G2/M. Gangguan atau hambatan pada fase $\mathrm{G} 2 / \mathrm{M}$ menyebabkan terjadinya kesalahan regulasi yang menyebabkan pembelahan sel tertunda, bahkan terhenti. ${ }^{20}$ Berhentinya siklus sel menggambarkan terjadinya mekanisme pertahanan diri sel kanker untuk memperbaiki kerusakan DNA. Penghentian siklus sel sebelum proses repair sempurna, akan mengaktivasi signal yang mengarah pada kematian sel. ${ }^{21}$

Profil siklus sel kombinasi secang 15 $\mu \mathrm{g} / \mathrm{mL}$ dan lempuyang $24 \mu \mathrm{g} / \mathrm{mL}$ menunjukkan peningkatan populasi sel di subG1 menjadi 2,7\%, sedangkan kontrol tanpa perlakuan $0,3 \%$. Peningkatan populasi sel di SubG1 mengindikasikan terjadinya kematian sel. Penelusuran jenis kematian sel yang terjadi, dilakukan dengan uji induksi apoptosis double staining PI dan anexin $\mathrm{V}$ menggunakan flow cytometer. Anexin akan mengikat lipid phosphatidylserine (PS), yang dalam kondisi normal berada di dalam membran plasma bagian dalam. Saat awal terjadi apoptosis, PS akan keluar ke bagian membran luar dan terikat anexin. Pada sel yang mengalami apoptosis lanjut dan nekrosis, anexin juga akan masuk ke dalam membran plasma. Sedangkan PI hanya bisa masuk pada sel yang mengalami kerusakan membran atau nekrosis. ${ }^{22}$

Profil kematian sel menunjukkan ekstrak rimpang lempuyang menginduksi terjadinya apoptosis lanjut berturut-turut sebesar 2,3\% dan 7,5\%. Sel apoptosis lanjut pada perlakuan secang tunggal belum memperlihatkan kenaikan yang berarti $(1,8 \%)$ dibandingkan kontrol $(0,8 \%)$. Lempuyang $24 \mu \mathrm{g} / \mathrm{mL}$ menginduksi nekrosis sebesar 9,2\%. Kombinasi secang dan lempuyang menunjukkan peningkatan sel apoptosis lanjut menjadi $13,7 \%$ dan sel nekrosis 10,0\% (Gambar 4). Menurut Crowley dkk., 2016, jumlah sel apoptosis dan nekrosis dalam suatu populasi tergantung pada dosis, durasi dan tingkat keparahan perlakuan. Pada perlakuan in vitro, apoptosis berlangsung dengan cepat selama beberapa jam, dan setelah itu sel mengalami nekrosis sekunder. ${ }^{22}$ Profil kematian sel pada perlakuan kombinasi menunjukkan kemiripan dengan profil lempuyang tunggal. Hasil penelitian Sithara dkk., 2017, zerumbon dosis 50 dan $75 \mu \mathrm{M}$ menginduksi apoptosis namun belum terjadi perubahan profil siklus sel. Pada dosis $100 \mu \mathrm{M}$ terjadi induksi apoptosis dan penghambatan siklus sel di fase $\mathrm{G} 2 / \mathrm{M}^{23}$

Apoptosis atau kematian sel terprogram merupakan proses yang berperan penting dalam perkembangan organisme dan homeostasis jaringan. Dalam kondisi patologis, terutama kanker, terjadi deregulasi ekspresi protein antiapoptosis sehingga sel terhindar dari kematian dan terus ber-proliferasi. ${ }^{24}$ Sel kanker juga mengalami disfungsi regulasi siklus sel, sehingga terjadi proliferasi yang tidak terkontrol dan atau terganggunya proses kematian sel terprogram. Penghambatan apoptosis selama proses karsinogenesis berperan sangat penting dalam perkembangan dan pertumbuhan sel kanker. ${ }^{25}$ Berdasarkan profil flow cytometry, sinergisme kombinasi dalam penelitian ini terjadi melalui penghambatan siklus sel di fase G2/M oleh ekstrak kayu secang, dan percepatan induksi apoptosis oleh rimpang lempuyang. 
A)
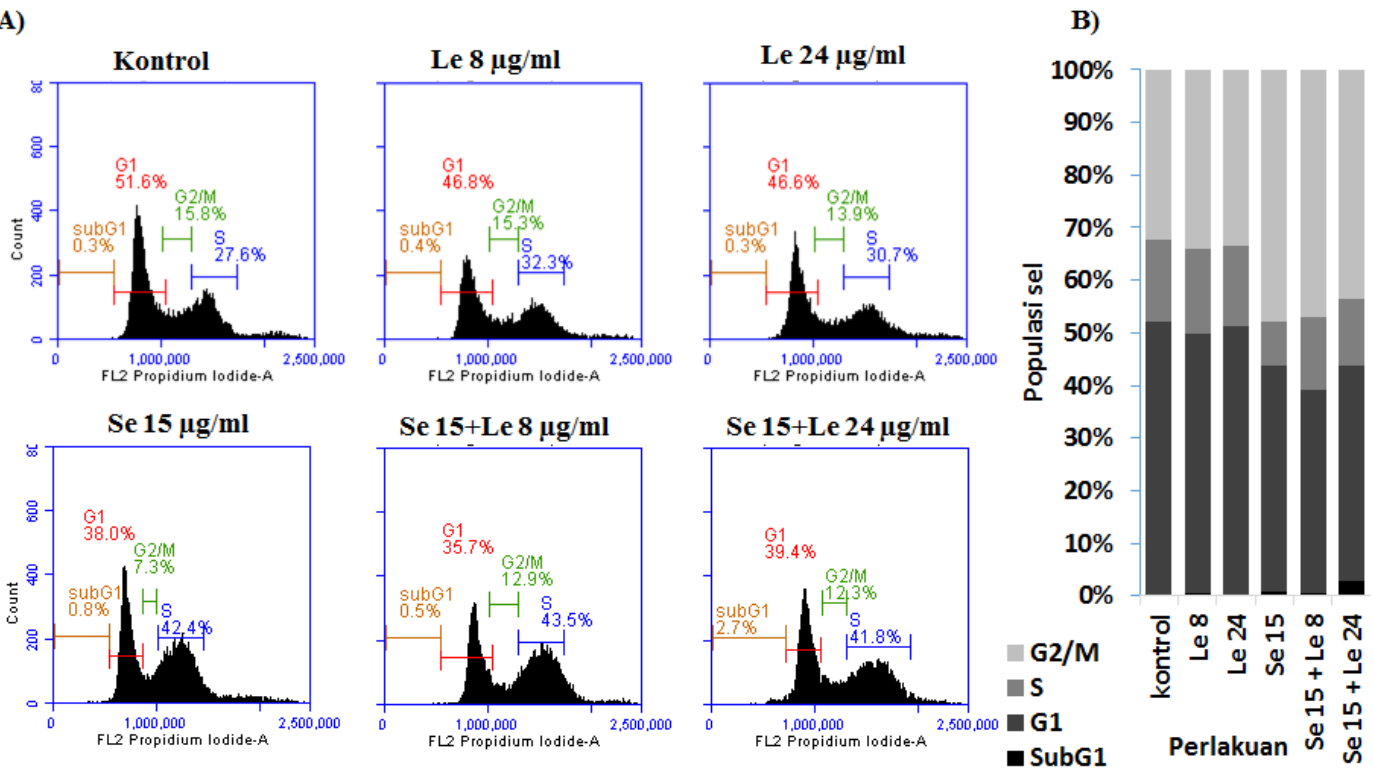

Gambar 3. Profil distribusi siklus sel perlakuan ekstrak tunggal dan kombinasi, dengan staining propidium iodide (PI) dan flow cytometry. Sel MCF-7 diberi perlakuan tunggal secang

(Se), lempuyang (Le) dan kombinasinya selama 24 jam. (A) Histogram siklus sel; (B) analisa populasi sel di setiap fase

A)
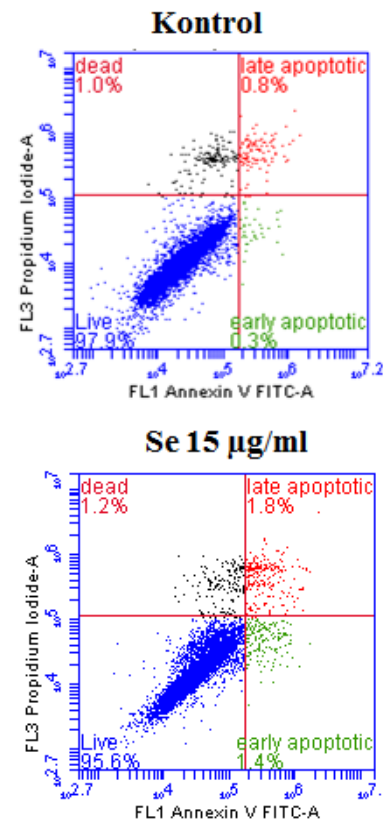
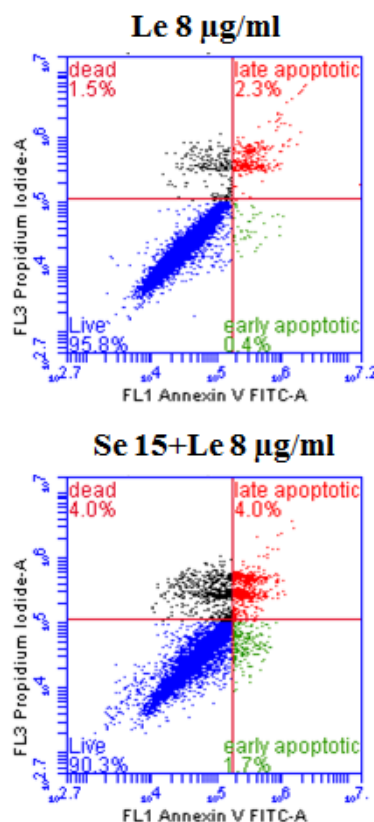

FL1 Annexin V FITC-A
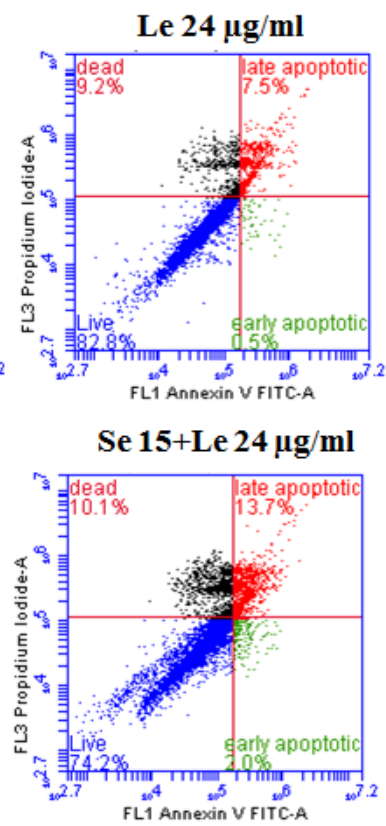

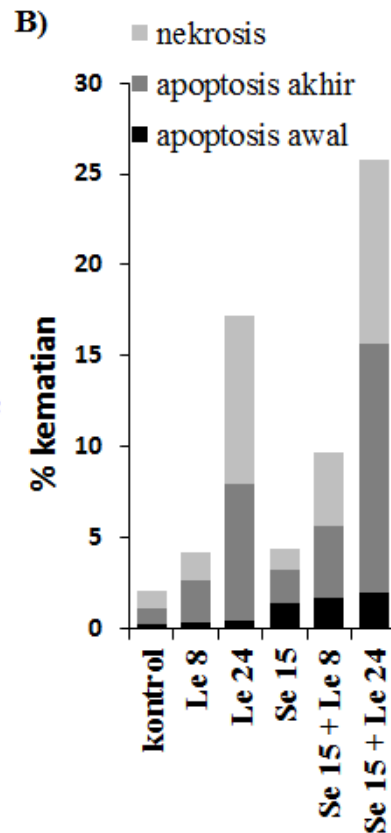

Perlakuan

Gambar 4. Deteksi sel apoptosis perlakuan ekstrak tunggal dan kombinasi, menggunakan doublestaining propidium iodide (PI) - annexin V dan flow cytometry. Sel MCF-7 diberi perlakuan tunggal secang (Se), lempuyang (Le) dan kombinasinya selama 24 jam. (A) Histogram sel apoptosis; (B) analisa \% kematian sel apoptosis/nekrosis

Apoptosis atau kematian sel terprogram merupakan proses yang berperan penting dalam perkembangan organisme dan homeostasis jaringan. Dalam kondisi patologis, terutama kanker, terjadi deregulasi ekspresi protein antiapoptosis sehingga sel terhindar dari kematian dan terus berproliferasi. $^{24}$ Sel kanker juga mengalami 
disfungsi regulasi siklus sel, sehingga terjadi proliferasi yang tidak terkontrol dan atau terganggunya proses kematian sel terprogram. Penghambatan apoptosis selama proses karsinogenesis berperan sangat penting dalam perkembangan dan pertumbuhan sel kanker. ${ }^{25}$ Berdasarkan profil flow cytometry, sinergisme kombinasi dalam penelitian ini terjadi melalui penghambatan siklus sel di fase G2/M oleh ekstrak kayu secang, dan percepatan induksi apoptosis oleh rimpang lempuyang.

\section{KESIMPULAN}

Kombinasi ekstrak etanolik kayu secang dan rimpang lempuyang menghasilkan efek sitotoksik yang sinergis. Sinergisme kombinasi terjadi melalui penghambatan siklus sel di fase G2/M oleh ekstrak kayu secang, dan percepatan induksi apoptosis oleh ekstrak rimpang lempuyang.

\section{SARAN}

Penelitian lebih lanjut diperlukan untuk mengkaji aktivitas penghambatan metastasis yang dihasilkan oleh kombinasi secang dengan lempuyang.

\section{UCAPAN TERIMA KASIH}

Penulis mengucapkan terima kasih kepada Akhmad Syaikhu, SKM, MS.c Kepala B2P2TO2T, yang telah memberikan dukungan fasilitas yang diperlukan dalam pelaksanaan penelitian dan penulisan artikel ini.

\section{DAFTAR RUJUKAN}

1. Che CT, Wang ZJ, Chow MSS, Lam CWK. Herb-herb combination for therapeutic enhancement and advancement: Theory, practice and future perspectives. Molecules. 2013;18(5):5125-41.

2. Ghoncheh M, Mohammadian-hafshejani A, Salehiniya $\mathrm{H}$. Incidence and mortality of breast cancer and their relationship to development in Asia. Asian Pac J Cancer Prev. 2015;16(14):6081-7.
3. Aung TN, Qu Z, Kortschak RD, Adelson DL. Understanding the effectiveness of natural compound mixtures in cancer through their molecular mode of action. Int $\mathbf{J}$ Mol Sci. 2017;18(3):1-20.

4. Nirmal NP, Rajput MS, Prasad RGS V, Ahmad M. Brazilin from Caesalpiniasappan heartwood and its pharmacological activities: $\{\mathrm{A}\}$ review. Asian Pac J Trop Med. 2015;8(6):421-30.

5. Haryanti S, Murwanti R, Putri H, Ilmawati GPN, Pramono S, Meiyanto E. Different 4T1 cells migration under Caesalpinia sappan L. and Ficus septica Burm.f ethanolic extracts. Indonesia $\mathrm{J}$ Cancer Chemoprevention. 2017 Feb;8(1):21-6.

6. Haryanti S, Pramono S, Murwanti R, Meiyanto E. The synergistic effect of doxorubicin and ethanolic extracts of Caesalpinia sappan L. wood and Ficus septica Burm.f. leaves on viability, cell cycle progression, and apoptosis induction of MCF - 7 cells. Indonesian Journal of Biotechnology. 2016;21(1):29-37.

7. Jenie RI, Handayani S, Susidarti RA, Udin Z, Meiyanto E. Cytotoxic and antimetastasis effect of ethyl acetate fraction from Caesalpinia sappan L. on MCF-7/HER2 cells. Indonesian Journal of Cancer Chemoprevention. 2017 Feb;8(1):42-50.

8. Yob NJ, Jofrry SM, Affandi MMRMM, Teh LK, Salleh MZ, Zakaria ZA. Zingiber zerumbet (L.) Smith: A review of its ethnomedicinal, chemical, and pharmacological uses. Evid Based Complement Alternat Med. 2011 Mar:543216.

9. Koga AY, Beltrame FL, Pereira A V. Several aspects of Zingiber zerumbet: a review. Rev Bras Farmacogn. 2016 Mei;26(3):385-91.

10. Murakami A, Tanaka T, Lee J-Y, Surh Y-J, Kim HW, Kawabata K, et al. Zerumbone, a sesquiterpene in subtropical ginger, suppresses skin tumor initiation and promotion stages in ICR mice. Int J Cancer. 2004 Jul;110(4):481-90.

11. Nakamura Y, Yoshida C, Murakami A, Ohigashi H, Osawa T, Uchida K. Zerumbone, a tropical ginger sesquiterpene, activates phase II drug metabolizing enzymes. FEBS Letters. 2004;572(13):245-50.

12. Tsuboi K, Matsuo Y, Shamoto T, Shibata T, Koide S, Morimoto $\mathrm{M}$, et al. Zerumbone 
inhibits tumor angiogenesis via NF- $\kappa \mathrm{B}$ in gastric cancer. Oncol Rep. 2014;31(1):5764.

13. Riss TL, Moravec RA, Niles AL, Duellman S, Benink HA, Worzella TJ, et al. Cell viability assays [Internet]. Assay guidance manual. Eli Lilly \& Company and the National Center for Advancing Translational Sciences; 2013 [dikutip 19 Maret 2018]. Tersedia pada: http://www.ncbi.nlm.nih.gov/pubmed/23805 433

14. Hemalatha K, Sunitha D, Satyanarayana D. Cytotoxic activity of ethanolic extracts of Caesalpinia sappan Linn and Anona squamosa Linn in A-549 cell line. Int J Pharm Ind Res. 2011;01(04):318-21.

15. Hung TM, Dang NH, Dat NT. Methanol extract from Vietnamese Caesalpinia sappan induces apoptosis in HeLa cells. Biol Res. 2014;47(1):1-5.

16. Nurzijah I, Putri DDP, Rivanti E, Meiyanto E. Secang (Caesalpiniasappan L.) heartwood ethanolic extract shows activity as doxorubicin co-chemotherapeutic agent by apoptotis induction on T47D breast cancer cells. Indonesian Journal of Cancer Chemoprevention. 2012;3(2):377-84.

17. Norfazlina MN, Zuraina MYF, Rajab NF, Nazip SM, Rumiza AR, Zaila CFS, et al. Cytotoxicity study of Nigella sativa and Zingiber zerumbet extracts, thymoquinone and zerumbone isolated on human myeloid leukemia (HL60) cell. In: The Open Conference Proceedings Journal. 2014; 99 107.

18. Handayani S, Susidarti RA, Jenie RI, Meiyanto E. Two active compounds from
Caesalpinia sappan L. in combination with cisplatin synergistically induce apoptosis and cell cycle arrest on WiDr cells. Adv Pharm Bull. 2017;7(3):375-80.

19. Kim B, Kim S-H, Jeong S-J, Sohn EJ, Jung $\mathrm{JH}$, Lee $\mathrm{MH}$, et al. Brazilin induces apoptosis and $\mathrm{G} 2 / \mathrm{M}$ arrest via inactivation of histone deacetylase in multiple myeloma U266 cells. J Agric Food Chem. 2012 Oct;60(39):9882-9.

20. Kelley MR, Logsdon D, Fishel ML. Targeting DNA repair pathways for cancer treatment: what's new? Futur Oncol. 2014;10(7):1215-37.

21. Carrassa L. Cell cycle, checkpoints and cancer. Atlas Genet Cytogenet Oncol Haematol. 2014;18(1):67-75.

22. Crowley LC, Marfell BJ, Scott AP, Waterhouse NJ. Quantitation of apoptosis and necrosis by annexin $\mathrm{V}$ binding, propidium iodide uptake, and flow cytometry. Cold Spring Harb Protoc. 2016 Nov;(11):953-7.

23. Sithara T, Dhanya BP, Arun KB, Sini S, Dan M, Kokkuvayil Vasu $R$, et al. Zerumbone, a cyclic sesquiterpene from Zingiber zerumbet induces apoptosis, cell cycle arrest, and antimigratory effects in SW480 colorectal cancer cells. J Agric Food Chem. 2018 Jan;66(3):602-12.

24. Mohammad RM, Muqbil I, Lowe L, Yedjou C, Hsu H-Y, Lin L-T, et al. Broad targeting of resistance to apoptosis in cancer. Semin Cancer Biol. 2015 Dec;35:S78-103.

25. Hassan M, Watari H, AbuAlmaaty A, Ohba Y, Sakuragi N. Apoptosis and molecular targeting therapy in cancer. Biomed Res Int. 2014:150845. 